\title{
Personality and marital surplus
}

\author{
Shelly Lundberg ${ }^{1,2^{*}}$
}

Correspondence: lundberg@econ.
ucsb.edu
'Department of Economics and
Broom Center for Demography,
2127 North Hall, University of
California, Santa Barbara, Santa
Barbara, CA 93106-9210, USA
${ }^{2}$ Department of Economics,
University of Bergen
Full list of author information is
available at the end of the article

Correspondence: lundberg@econ. Brom Center for Demography, North Hall, University of Barbara, CA 93106-9210, USA 2Department of Economics, Full list of author information is

\section{Springer}

\begin{abstract}
This paper uses data from the German Socio-economic Panel Study to examine the effect of personality traits on the formation and dissolution of domestic partnerships. Selection into marriage is associated with distinctly different personality profiles for men and women born before 1960, suggesting that gender-specialized contributions to household public goods were an important source of marital surplus for these cohorts. The effects of personality on marriage are more similar for younger men and women; this is consistent with marital returns based on joint consumption. Divorce is associated with low expected marital surplus, low emotional stability for women, and male extroversion.

JEL Code: J12
\end{abstract}

\section{Introduction}

The formation and dissolution of marital and cohabiting relationships have important implications for individual wellbeing and for society. Stable partnerships are associated with higher incomes, improved health and happiness, and positive child outcomes. Economic models of marriage and divorce postulate that decisions to begin and end a domestic partnership are driven by the expected and realized surplus to marriage, compared with single life. ${ }^{1}$ These positive returns to marriage include the extra resources generated by specialization and exchange in multi-person households and the consumption benefits of household public goods. The declining prevalence and stability of marriage in wealthy industrialized societies have been explained as consequences of reduced returns to marriage as women's market work increases and production complementarities within the household become less important (Lundberg and Pollak, 2007; Stevenson and Wolfers, 2007). This suggests that the gains individuals receive from marriage and cohabitation has become increasingly consumption-based, but the evidence for this is largely indirect and based on the observed decrease in specialization within marriage.

In this paper, I provide additional evidence that the sources of marital surplus have changed among German couples since the 1970s. Using individual personality traits as indicators of heterogeneous preferences and capabilities that influence marital surplus, I show that production complementarities imply a different sorting of men and women into marriage than do consumption complementarities. The empirical relationships between personality and relationship formation and dissolution for post-war cohorts of a large representative sample of German men and women indicate that the determinants of marital surplus changed substantially between men and women born in the years immediately after World War II and younger cohorts born in the 1960s. These changes were consistent with a shift to consumption-intensive marriages despite very modest changes in women's market work across these cohorts.

(c) 2012 Lundberg; licensee Springer. This is an Open Access article distributed under the terms of the Creative Commons Attribution License (http://creativecommons.org/licenses/by/2.0), which permits unrestricted use, distribution, and reproduction in any medium, provided the original work is properly cited. 
Returns to marriage and cohabitation that are due to production complementarities are enhanced by the mating of individuals with different capabilities who can benefit from specialization in different activities and exchange within the household (Becker, 1981). Consumption complementarities, such as those due to joint public goods consumption, are of greatest benefit if individuals with similar preferences for consumption and leisure are matched (Lam, 1988). As noted by Borghans et al. (2008), personality traits seem, intuitively, to be related both to preferences (conscientious people place a high value on order, and extraverts prefer social interaction to solitude) and to capabilities (conscientious people are self-disciplined at school; introverts perform poorly in sales jobs). If personality traits are predictive of individual contributions to marital surplus, either through market/domestic productivities or tastes for household public goods, then they should also predict individual selection into and out of marriage. Thus, the empirical relationship between personality traits and demographic outcomes should be informative, both about the relative significance of consumption-based and production-based gains to marriage and about the economic interpretation of personality.

We know that economic factors such as educational attainment and market wages are predictive of age at marriage and the probability of divorce, but much of the individual variation in marital histories remains unexplained. Economists have begun explore the role of psychological traits, including personality, motivational factors, and preferences, as determinants of labor market outcomes, ${ }^{2}$ but the impact of psychological variables on social and demographic behaviors remains largely unstudied in economics. Psychologists and sociologists have examined the relationship between personality and family outcomes such as fertility and marital satisfaction, but most of these analyses are based on relatively small samples. The recent availability of psychological variables in large representative surveys such as the German Socio-economic Panel Study and the British Household Panel Study present new opportunities for economists and other social scientists to study their association with a wide range of lifetime experiences, and to reconsider how we model the formation and stability of families and the living arrangements of children.

This paper uses data from the German Socio-economic Panel Study (SOEP), which contains an array of psychological and preference indicators (most gathered in recent waves of the survey), and relates these to lifecycle demographic outcomes for cohorts up to age 59 in 2005. Personality traits are treated as indicators of preferences and capabilities that shape the returns to marriage and the ability of partners to solve problems and make long-term commitments. A caveat to the interpretation of the empirical results is that, although personality has been found to be extremely stable over the adult lifespan, we cannot rule out the possibility that measured traits have been influenced by marital histories.

For the full sample, I find evidence both of common factors in the sorting of men and women into marriage and divorce (openness to experience and conscientiousness), and of distinct gender differences in the effects of other traits (agreeableness increases the probability of marriage for women and decreases marriage for men, while extroversion and neuroticism are significant only for women). For the older cohorts, the results suggest that contributions to marital surplus were to some extent gender-specialized, with men providing material and women emotional contributions to their joint domestic enterprise. For younger cohorts, openness and conscientiousness are important determinants of transitions into and out of marriage, and their effects on the marriage probabilities of men and women are not significantly different. In general, individual personality traits are important 
indicators of marital surplus, and the cohort results are consistent with a shift in the sources of marital surplus from specialized domestic production for post-war birth cohorts of men and women to joint consumption for younger cohorts born in the 1960s. Propensities to divorce appear to be related both to low marital surplus and to low emotional stability (which may inhibit marital negotiation) and to the availability of alternatives.

\section{Marriage and divorce}

Since 1950, patterns of family formation and dissolution have undergone a transformation known as the second demographic transition (Lesthaege, 2010) in most wealthy market economies. Marriage and childbearing have been delayed, cohabitation rather than formal marriage is increasingly prevalent, and partnerships are less stable. Since union formation and dissolution are strongly linked to the lifetime wellbeing of men, women, and children, understanding the determinants of an individual's family status has become more salient for policy as variability in family histories, both across individuals and socioeconomic groups, has increased.

Economists consider marriage (and domestic partnership in general) to be the outcome of choices by individuals who expect to enjoy private gains from the establishment of a joint household. Since men and women decide to marry on the basis of a comparison of their expected utility in two states-married and single-the decision depends both on the magnitude of the expected marital surplus and on the partners' ability to make a credible commitment regarding the division of the surplus. ${ }^{3}$ The gains from marriage arise from both joint production and joint consumption in the household, and have several distinct sources. Production-based gains come from economies of scale in domestic production and from the returns to specialization and exchange within the household; consumption benefits arise from risk pooling, the joint consumption of household public goods (including children), and the direct utility of time spent together.

A focus on production complementarities and specialization within the household leads to the standard prediction that there should be negative assortative mating based on market wages (Becker, 1981): the hard-driving careerist marries the happy homemaker. The gains to matching individuals with complementary skills should also apply to other individual capabilities relevant to household production-there will be potential gains to the marriage of an accomplished cook to a keen gardener. However, as women's labor force participation has increased and the relative significance of household (rather than market) production has declined, complementarities in consumption have become more important sources of the gains to marriage (Stevenson and Wolfers, 2007). This implies that positive assortative mating on traits related to preferences for household consumption-a shared interest in children, modern art, or loud parties, for example-should have become increasingly important (Lam, 1988). Isen and Stevenson (2010) document the changes in American women's family behavior since 1950 and note that the observed increase in assortative mating by education, which should be correlated with preferences for time use and consumption as well as the price of market time, is consistent with increasingly consumption-based marriage.

Analyses of selection into and out of marriage and of assortative mating have focused on individual characteristics that are readily available on large samples, such as education, race and ethnicity, and family background (Schwartz and Mare, 2005; Furtado and 
Theodoropoulos, 2011; Chiswick and Houseworth, 2011). New data on personality, which is both a relatively stable set of individual traits and is strongly predictive of behavior and of economic and social outcomes, provide new opportunities to examine the determinants of marital surplus. Personality inventories are intended to be descriptive of stable differences in individual dispositions. There are many alternative taxonomies, but the "Big Five" personality inventory is broadly accepted as a consistent and reliable categorization of attributes that people find "important and useful in daily interactions" (Goldberg, 1981). The Big Five measures individual differences across five broad traits: openness, conscientiousness, agreeableness, extraversion, and neuroticism (or its converse, emotional stability).

In an evolutionary context, the five-factor model may identify individual variations on behavioral dimensions that are significant to human social acceptance and status in groups. McAdam and Pals (2006) identify these facets of social interaction and their associated personality traits as social dominance (extraversion), negativity and instability (neuroticism), cooperation (agreeableness), trust and commitment (conscientiousness), and openness to change and learning (openness to experience). At a more micro-level, these modes of interaction are also relevant to mating and successful pair-bonding-a conscientious mate will be more trustworthy and more likely to fulfill a marital commitment.

Though a recent literature in economics has examined the cross-sectional relationship between personality indicators and labor market outcomes, ${ }^{4}$ the effect of personality on demographic outcomes in large samples is almost unexplored. An exception is a set of recent studies of fertility and fertility timing. Jokela et al. (2009) review a small set of studies in psychology on personality and childbearing and estimate the relationship between personality and parenthood using a large longitudinal survey $(\mathrm{N}=1,839)$ of young Finns. They find that emotionality (related to neuroticism) and sociability (related to extraversion) are associated with the probability of having children for both men and women. Tavares (2008) examines the relationship between Big Five personality traits and age at first birth for women in the British Household Panel Survey and finds that agreeableness, extraversion, and neuroticism accelerate childbearing, while conscientiousness and openness delay it. ${ }^{5}$

Measured psychological characteristics, including personality, may reflect individual variation in both preferences and capabilities. Tavares (2008) interprets the correlations she finds between personality and fertility timing as reflective of individual women's underlying preferences and motivations for childbearing. Borghans et al. (2008) discuss the relevance of personality to economics and the relevance of economics to personality psychology. They provide some analytic frameworks for linking personality psychology and economics and argue that personality traits, as well as cognitive ability, may impose constraints on individual choices and, in turn, "conventional economic preference parameters can be interpreted as consequences of these constraints" (p. 997). For example, high rates of time preference may be caused by an individual's inability to delay gratification, or by an inability to imagine the future.

It is possible to construct simple models of personality and marital surplus in which "preference" and "constraint" interpretations of personality have distinct predictions for empirical relationships between individual traits and marriage behavior. In the first model presented below, personality affects individual tastes for a household public good and, in the second, personality traits are indicators of productive capabilities. In this context, the two types of economic interaction that create marital surplus-household production and 
joint consumption-have contrasting implications for how individual traits affect the decision to marry. If a personality trait has the same effect on the probability of marriage for men and women, we can infer that it is related to the consumption benefits of marriage, and therefore to individual preferences. If gender-based specialization is an important source of marital surplus, however, we would expect different capabilities to promote the marriages of men and women. If psychological traits primarily reflect individual capabilities rather than preferences, then trait effects on marriage will differ by gender.

Suppose, first of all, that the gains to marriage depend on the joint consumption of a marriage-specific public good that is purchased in the market. Each individual $i$ in a prospective couple has a continuous, quasi-concave utility function that is monotone increasing in consumption of a household public good, $Q$, and a private good, $x_{i}$. $Q$ is purchased in the market at a price $p$. Let preferences take the quasi-linear form:

$$
U_{i}\left(Q, x_{i}\right)=A(Q) x_{i}+B_{i}(Q)
$$

which permits utility to be transferable within the household through reallocations of the private good. ${ }^{6}$ A married couple consisting of person 1 and person 2 is assumed make decisions cooperatively and, with transferable utility, the efficient level of the household public good is independent of the distribution of income that household bargaining determines. The optimal value of $Q$ satisfies the Samuelson condition

$$
M R S_{1}+M R S_{2}=A^{\prime}(Q)\left(x_{1}+x_{2}\right)+B_{1}^{\prime}(Q)+B_{2}^{\prime}(Q)+p
$$

and the pooled household budget constraint $x_{1}+x_{2}+p Q=Y_{1}+Y_{2}$ where $Y_{i}$ is the exogenous income of individual $i$.

Model 1: Marital Consumption. For simplicity, let $B_{i}(Q)=\beta_{i} Q$ with $\beta_{i}>0$ so that a single parameter defines individual preferences for the household public good. Substituting the budget constraint into the Samuelson condition implies $Q$ as a function of income, prices, and the preference parameters and, not surprisingly, $Q$ is increasing in $\beta_{1}$ and $\beta_{2}$.

Let utility when married include a direct return to marriage, $c_{i}^{m}$, that is randomly distributed over the population, may be positive or negative, and is independent of partner's characteristics. Single individuals are assumed to have the same preferences as married individuals, but we assume that single households do not consume any of the public good, so that all income is spent on the private good. If $A(0)=1$, then single utility is $U_{i}^{s}\left(Y_{i}\right)=Y_{i}$

This implies that total marital surplus for the couple will be

$$
S=U_{1}^{m}+U_{2}^{m}-U_{1}^{s}-U_{2}^{s}=A(Q)\left(x_{1}+x_{2}\right)+\left(\beta_{1}+\beta_{2}\right) Q+c_{1}^{m}+c_{2}^{m}-Y_{1}-Y_{2}
$$

and individuals 1 and 2 will marry if $S>0$. In a general model with transferable utility in which potential spouses vary only in wealth, Lam (1988) shows that there will be positive assortative mating on wealth, since there are positive returns to choosing a spouse with similar demands for the public good. We are concerned here with preferences rather than wealth, and marital surplus is increasing in both $\beta_{1}$ and $\beta_{2}$, the relative preferences for the marriage-exclusive public good.

Suppose that a personality trait $z_{0}$ influences preferences so that $\beta_{i}\left(z_{o i}\right)$ and $\frac{\partial \beta}{\partial z_{0}}>0$. In this case, household public goods and total marital surplus will be increasing in $z_{0}$ for both men and women. For a woman with personality $z_{01}^{*}$, there will be some value of a potential partner's trait $\bar{z}_{02}\left(z_{01}^{*}\right)$ such that $S \geq 0$ for all partners for whom $z_{02} \geq \bar{z}_{02}$. If there is random 
matching in the marriage market, then the probability that this woman marries is equal to the probability that a randomly-selected partner has personality trait $z_{02} \geq \bar{z}_{02}$, and this probability will be increasing in the value of her personality trait. Therefore, individuals with greater preferences for marital public goods are more likely to marry. With assortative matching, the marginal effect of $z_{0}$ on the probability of marriage will be even stronger.

This model predicts that men and women with high relative preferences for jointlyconsumed goods such as children (agreeableness, for example), companionship (extraversion), and conformance with social conventions (conscientiousness) will tend to marry or cohabit with like-minded individuals rather than remain single. If consumption complementarities are the principal source of gains to marriage, we should observe similar patterns of selection into marriage by personality for men and for women.

Model 2: Marital Production. Production complementarities in the household, on the other hand, imply differential selection into marriage for men and women. Suppose that, instead of being purchased in the market, the marital public good is produced in the household with inputs of spousal time, $t=\alpha_{1} t_{1}+\alpha_{2} t_{2}$ (with $\alpha_{i} \geq 0$ ), and purchased goods, $G$, so that $Q=F(t, G)$. Individual time endowments, $T$, are allocated to household production time and market work $\left(h_{i}\right)$, which is compensated at fixed wage rates $\left(w_{i}\right)$. As in the previous model, a cooperative couple chooses the efficient level of the public good, in this case subject to the production function and the time and budget constraints:

$$
\begin{aligned}
& T=t_{1}+h_{1}=t_{2}+h_{2} \\
& w_{1} h_{1}+w_{2} h_{2}=x_{1}+x_{2}+p_{G} G
\end{aligned}
$$

This is Becker's model of household production, and since the time of persons 1 and 2 are perfect (quality-adjusted) substitutes in both home and market work, it leads to complete specialization-the husband and wife will not both supply positive hours to the home and market sectors.

Suppose that market productivity $w$ is enhanced by a personality trait, $z_{a}$-conscientiousness, for example-and home productivity $\alpha$ is increasing in a different trait, $z_{b}$. In a labor market with a substantial gender gap in wage schedules such that $w_{2}\left(\bar{z}_{a}\right)>w_{1}\left(\bar{z}_{a}\right)$, women will tend to specialize in household activities and men in market activities unless their relative endowments of productivity-enhancing traits is strongly skewed towards the other sector. Marital surplus will clearly be increasing in $z_{b}$, since it increases the productivity of time spent in production of the marital public good. In general, a $z_{a}$-induced increase in wage rates will have both income and substitution effects on the production of $Q$, but in a specialized household increases in men's wages will increase marital surplus. Also, if men do no housework, their endowment of $z_{b}$ will not influence their selection into marriage. With random marital matching, women's probability of marriage will be increasing in $z_{b}$ and men's marriage probability will be increasing in $z_{a}$. Since female $z_{b}$ and male $z_{a}$ are complements in production, assortative matching will increase the marginal effect of each trait on marital surplus, and increase this dependence of marriage probabilities on distinct male and female traits.

Models 1 and 2 show that production complementarities and consumption complementarities imply different patterns of selection into marriage for men and women (as long as specialization in household production is gender-based). ${ }^{7}$ Although we observe strong 
positive assortative mating on a variety of individual characteristics, including education, wages, religion, and ethnicity, there is some empirical evidence that potential gains to specialization also affect the propensity to marry. For example, Xie et al. (2003) show that potential earnings increase the likelihood of marriage for men, but not women. A priori, we expect the differential selection of men and women into marriage by personality traits predicted by the household production model to have decreased over the past few decades for two reasons. One, falling fertility and changes in the relative price of home time and market substitutes have substantially reduced hours devoted to household production (Aguiar and Hurst, 2007). As wage rates rise and the price of market inputs falls, efficient household production has become more goods-intensive and this "marketization" of household activities should cause the influence of personality traits that affect sector-specific productivity to fall. Two, decreased gender discrimination in labor markets and weakening social norms that restrict women to the home sphere imply that the determinants of marital surplus will be less gender-specific.

We can also expect the marginal impact of individual characteristics on cohabitation, age at marriage and divorce to increase with the erosion of social norms concerning traditional family arrangements and the emergence of greater diversity in family histories. For example, education had no significant association with the marital status of men in the U. S. Panel Study of Income Dynamics in 1970 but by 2001, when the proportion married was much smaller, marriage and education had a strong positive correlation (Lundberg, 2005). Similarly, increasing levels of discretion in family arrangements should lead to a greater role for personality and preferences in explaining family behavior (Tavares, 2008).

The predicted effect of personality traits on individual propensities to divorce also begins with the determinants of marital surplus. The essence of the economic theory of divorce is stated in the classic paper by Becker, Landes and Michael (1977) - a couple divorces when they have "less favorable outcomes from their marriage than they expected when marrying" (p. 1142). Members of a newly-married couple will be uncertain about each other's true nature and the characteristics of their future children, about their future earnings prospects and health conditions. As information about the quality of their match and the value of their alternatives arrives, surprises can lead to a dissipation of the marital surplus and divorce. For example, Weiss and Willis (1997) find that negative shocks to men's earnings (but not women's earnings) increase divorce probabilities. Charles and Stephens (2004) show that the information content of an earnings shock may be more important than the shock itself. They find that the divorce hazard rises after a spouse's job displacement but not after a disabling health shock, and that job loss only increases divorce if it is due to a layoff, not a plant closing.

If legal restrictions or social norms make divorce costly, then marital dissolution will only occur if shocks to the perceived quality of this marriage or the attractiveness of alternative partners renders marital surplus sufficiently negative that it is worthwhile to pay these costs. Individual commitment to marriage can also be thought of as a source of (psychic) divorce costs that make dissolution less likely. If surprises arrive that leave marital surplus positive but that change the value of marital alternatives for one partner, some redistribution may be required to maintain the marriage with positive surplus for both partners. Peters (1986) shows that, if the marital surplus cannot be reallocated (due, for example, to asymmetric information) then 'inefficient' divorces may occur. 
In general, then, we would expect divorce to be more likely when marital surplus and divorce costs (or commitment) are low, when the cost of renegotiating the marital contract following shocks is high, and when alternative relationships are more readily available. In terms of individual traits, this suggests that individuals who are more impulsive and desirous of variety (openness), more extraverted, and less conscientious may be more likely to divorce. Environment as well as individual traits may also be important for the arrival of alternative partnership opportunities-McKinnish (2004) shows that workplace contact between men and women appears to increase divorce. Finally, neuroticism may inhibit negotiation and make an individual more divorce-prone.

There is some support for these hypotheses in psychological studies. In a sample of 431 male physicians, McCranie and Kahan (1986) found that socially non-conforming, impulsive, risk-taking, stimulus-seeking men were more likely to have multiple divorces. In terms of the Big 5 traits, this would lead us to expect that low conscientiousness and high openness to experience are associated with a high probability of divorce. Marital instability has also been shown to be associated with neuroticism (Kiernan, 1986; Lowell and Conley, 1987), low agreeableness in women and extraversion in men (Kinnunen et al., 2000). A comprehensive review of this literature by Roberts et al. (2007) finds consistent effects of neuroticism, agreeableness, and conscientiousness on divorce and concludes that the likely explanation for this association is that "personality helps shape the quality of long-term relationships" (p. 327).

\section{Data and measures}

This study uses data from the German Socio-economic Panel Study (SOEP), a representative longitudinal survey of households and individuals in Germany (Wagner et al., 2007). The initial wave of the survey was conducted in 1984, and consisted of 12,000 randomlyselected respondents in West Germany in 1984. In 1990, following re-unification, a sample from East Germany was added, followed by a sample of immigrants in 1994 and several additional samples. This study uses all samples available in 2005 except the high income test sample and sample weights are used in all analyses.

The analysis sample is derived from the 2008 95\% Scientific Use File of SOEP, and consists of 7,111 household heads, spouses, and partners aged 35 to 59 in 2005 with nonmissing data for all variables. Results are presented for the full sample and separately for two birth cohorts-men and women born between 1945 and 1959 (old), and those born between 1960 and 1970 (young). Table 1 presents means and standard deviations for key variables. The SOEP conducts a separate interview with each member of a household over age 17 , so that all information is self-reported.

The key dependent variables are life-cycle family outcomes that can be observed for these birth cohorts-ever-married by age 35 and whether the first marriage ended in divorce by the end of the sample period. Table 1 also reports the proportion of each cohort married by age 25 and the mean age at first marriage. These variables are constructed from the Marital Biography File, and do not distinguish between legal marriage and cohabitation-both are termed "marriage." Despite the inclusion of cohabitation in this measure, the older cohorts "married" earlier than the young cohorts. The mean age at first marriage is 23 for the older women and 26 for the older men, compared to 24.6 for the young women and 27 for the young men. Marriage rates are very high for the older cohorts (93 and 87 percent for 
Table 1 Sample means

\begin{tabular}{|c|c|c|c|c|c|c|}
\hline & \multicolumn{3}{|c|}{ Women } & \multicolumn{3}{|c|}{ Men } \\
\hline & $\begin{array}{c}\text { Full } \\
\text { Sample }\end{array}$ & $\begin{array}{l}\text { Older Cohorts: } \\
\text { 1945-1959 }\end{array}$ & $\begin{array}{c}\text { Younger Cohorts: } \\
1960-1970\end{array}$ & $\begin{array}{l}\text { Full } \\
\text { Sample }\end{array}$ & $\begin{array}{l}\text { Older Cohorts: } \\
1945-1959\end{array}$ & $\begin{array}{c}\text { Younger Cohorts: } \\
1960-1970\end{array}$ \\
\hline $\begin{array}{l}\text { Ever Married by } \\
\text { Age } 25\end{array}$ & 0.66 & 0.76 & 0.56 & 0.46 & 0.56 & 0.35 \\
\hline $\begin{array}{l}\text { Ever Married by } \\
\text { Age } 35\end{array}$ & 0.90 & 0.93 & 0.86 & 0.82 & 0.87 & 0.77 \\
\hline $\begin{array}{l}\text { Age at First } \\
\text { Marriage }\end{array}$ & 23.7 & 22.9 & 24.6 & 26.5 & 26.0 & 27.0 \\
\hline $\begin{array}{l}\text { Ever Divorced } \\
\left(1^{\text {st }} \text { marriage }\right)\end{array}$ & 0.24 & 0.24 & 0.24 & 0.21 & 0.26 & 0.18 \\
\hline Age in 2005 & 46.0 & 51.8 & 40.1 & 46.0 & 52.0 & 40.1 \\
\hline Years of Education & 12.1 & 11.8 & 12.3 & 12.4 & 12.3 & 12.5 \\
\hline $\begin{array}{l}\text { Labor income } \\
2005^{*}\end{array}$ & 1746 & 1812 & 1683 & 3235 & 3272 & 3200 \\
\hline $\begin{array}{l}\text { Labor force } \\
\text { participation } 2005\end{array}$ & 0.64 & 0.61 & 0.66 & & & \\
\hline $\begin{array}{l}\text { Some religion } \\
\text { reported }\end{array}$ & 0.68 & 0.67 & 0.69 & 0.62 & 0.62 & 0.63 \\
\hline German ethnicity & 0.92 & 0.92 & 0.93 & 0.92 & 0.93 & 0.91 \\
\hline $\begin{array}{l}\text { East Germany } \\
\text { sample }\end{array}$ & 0.17 & 0.18 & 0.16 & 0.17 & 0.18 & 0.15 \\
\hline Observations & 3642 & 1830 & 1812 & 3469 & 1735 & 1734 \\
\hline
\end{tabular}

* Labor force participants only.

women and men, respectively) and even for men in the younger cohorts, 77 percent have married/cohabited by age 35. About one-quarter of the ever-married older cohorts experienced a divorce from their first marriage by 2007, compared to 24 percent of the young women and 18 percent of the young men. The younger cohorts of men are less likely to have divorced in part because the elapsed time between their marriage date and the end of the sample period is much shorter-an average of 13 years versus 26 for the older cohorts.

Mean years of education are roughly constant across cohorts for men, but increase from 11.8 years to 12.3 years for women. The labor force participation rate for women, defined as the proportion of the sample with positive labor income in 2005, is only slightly higher for the younger cohorts (66 percent versus 61 percent for the older cohorts), as many of them still have young children at home in 2005. Many of the younger women who work do so part-time and their total earnings are lower in 2005, both in absolute terms and relative to male earnings, than the earnings of the older female cohorts. Even though we might expect the better-educated women born after 1960 to have a greater lifetime attachment to the labor force than those born in the post-war years, the low rates of maternal employment in Germany imply that only a very small decrease in gender specialization across cohorts is apparent at this point in the lifecycle. ${ }^{8}$ Additional control variables include dummies for German ethnicity, for inclusion in the East German sample, and for the report of some religion (vs. "none").

The main independent variables are the personality traits-openness to experience, agreeableness, extraversion, neuroticism, and conscientiousness. Each personality trait 
incorporates a variety of detailed attributes that tend to be correlated, and "the Big 5 are fairly independent dimensions that can be measured with convergent and discriminant validity" (John and Srivasta, 1999). There is a long history of testing for internal validity, but external validity assessments are more limited, and tend to be focused on small samples. Recent reviews by Roberts et al. (2007) and Ozer and Benet-Martinez (2006), however, emphasize the ability of personality traits to predict important life outcomes, including health and happiness, the quality of peer and romantic relationships, and occupational choice.

The SOEP 2005 survey includes a short-scale version of the Big Five personality inventory. Each trait is constructed from three items in which the respondent assesses how well a descriptive phrase applies to them (Table 2) using a 7-point Likert scale. The average scores for each trait have been age-normed (with a quadratic in age) and standardized separately by gender.

Table 2 Personality traits and preferences, SOEP questions

\begin{tabular}{ll}
\hline Big Five: I see myself as someone who ... (7-point scale from 'applies to me perfectly' to 'does not apply to \\
me at all') & Openness to Experience \\
is original, comes up with new ideas & Openness to Experience \\
values artistic experiences & Openness to Experience \\
has an active imagination & Conscientiousness \\
does a thorough job & Conscientiousness \\
does things effectively and efficiently & Conscientiousness \\
tends to be lazy (reversed) & Extraversion \\
is communicative, talkative & Extraversion \\
is outgoing, sociable & Extraversion \\
is reserved (reversed) & Agreeableness \\
is sometimes somewhat rude to others (reversed) & Agreeableness \\
has a forgiving nature & Agreeableness \\
is considerate and kind to others & Neuroticism \\
worries a lot & Neuroticism \\
gets nervous easily & Neuroticism \\
is relaxed, handles stress well (reversed) & \\
Risk aversion: (10-point scale) & \\
Are you generally a person who is fully prepared to take risks, or do you avoid taking risks? \\
\hline
\end{tabular}

The Big 5 personality traits are defined as follows by Hogan and Hogan (2007):

Openness vs. closedness to experience: The degree to which a person needs intellectual stimulation, change and variety.

Conscientiousness vs. lack of direction: The degree to which a person is willing to comply with conventional rules and norms.

Agreeableness vs. antagonism: The degree to which a person needs pleasant and harmonious relations with others.

Extraversion vs. introversion: The degree to which a person needs attention and social interaction.

Neuroticism vs. emotional stability: The degree to which a person experiences the world as threatening and beyond his or her control. 
One issue in treating personality as a causal determinant of labor market success or family behavior concerns the stability of personality traits over the adult lifecycle and possible endogeneity of personality and other traits with respect to an individual's family history. Since personality is assessed in the 2005 survey and marital histories include events in previous years, any causal interpretation of these results requires that measured personality be unaffected by the experience of marriage or divorce. ${ }^{9}$

Existing longitudinal research has suggested that personality is not affected by major life events, though we cannot rule out the possibility of some reverse causality. ${ }^{10}$ The rank-ordering of individuals is quite stable over time and, though there is some instability in early adulthood (Roberts and DelVecchio, 2000), temporal correlations in longitudinal studies commonly exceed 0.9 (Costa and McCrae, 1997). ${ }^{11}$ According to Caprara and Cervone (2000), "the relative stability of adults' self-reports is one of the most robust findings in the personality psychology literature" (p. 146). Recent longitudinal analyses of personality retests in both SOEP and the Household, Income and Labour Dynamics in Australia (HILDA) surveys find that traits are very stable over a four-year period (Specht, Egloff, and Schmukle, 2011; Cobb-Clark and Schurer, 2011). Cobb-Clark and Schurer find little evidence that adverse life events affect personality and, while Specht et al. find a few significant associations between major life events and specific traits, there is no evident pattern to the results. ${ }^{12}$

Also included in some models as a test of the stability of the personality effects is a measure of risk aversion included in the 2004 wave of SOEP. Dohmen et al. (2011) examine the validity of the SOEP risk aversion and show that it predicts risk-taking behavior in investment, career choice, smoking, and other domains. Though the relationship between personality traits and preference parameters such as risk aversion is a priori unclear, Becker et al. (2012) report weak associations between personality traits and a range of economic preference measures and find that they are complementary factors in explaining outcomes such as wages, reported health, and education.

\section{Results}

\subsection{Marriage}

Table 3 reports average marginal effects from a probit model in which the dependent variable is a dummy indicating whether the man or women was ever-married by age 35. Included in the model are Big 5 personality traits (columns 1 and 2) and personality traits plus risk aversion and years of education (columns 3 and 4). The models in columns 5 and 6 also include a dummy for German ethnicity, a dummy for inclusion in the East German sample ${ }^{13}$ and a dummy for the reporting of some religious affiliation.

The effects of individual personality traits on the marriage probabilities of men and women are quite distinct, though there are two common elements in all specifications-openness to experience decreases marriage for both men and women, while conscientiousness increases the probability of marriage. Marriage for women is also positively related to extraversion, agreeableness, and neuroticism, and the effects are generally robust to the inclusion of the other demographic and preference variables. Marriage for men is positively related to antagonism (the converse of 
Table 3 The probability of marriage by age 35: full sample

\begin{tabular}{|c|c|c|c|c|c|c|c|}
\hline & Women & Men & Women & Men & Women & Men & $\beta_{m} \neq \beta_{f}$ \\
\hline & 1 & 2 & 3 & 4 & 5 & 6 & (p-value) \\
\hline \multicolumn{8}{|l|}{$\begin{array}{l}\text { "Big 5" Personality } \\
\text { Traits }\end{array}$} \\
\hline $\begin{array}{l}\text { Openness to } \\
\text { Experience }\end{array}$ & $\begin{array}{l}-0.044^{* * *} \\
(0.010)\end{array}$ & $\begin{array}{l}-0.034^{* *} \\
(0.014)\end{array}$ & $\begin{array}{l}-0.032^{* * *} \\
(0.010)\end{array}$ & $\begin{array}{l}-0.027^{*} \\
(0.015)\end{array}$ & $\begin{array}{l}-0.032^{* * *} \\
(0.010)\end{array}$ & $\begin{array}{l}-0.025^{*} \\
(0.014)\end{array}$ & 0.684 \\
\hline Conscientiousness & $\begin{array}{l}0.031^{* * *} \\
(0.010)\end{array}$ & $\begin{array}{l}0.055^{* * *} \\
(0.013)\end{array}$ & $\begin{array}{l}0.027^{* * *} \\
(0.010)\end{array}$ & $\begin{array}{l}0.050^{* * *} \\
(0.013)\end{array}$ & $\begin{array}{l}0.026^{* * *} \\
(0.009)\end{array}$ & $\begin{array}{l}0.050^{* * *} \\
(0.013)\end{array}$ & 0.129 \\
\hline Extraversion & $\begin{array}{l}0.037^{* * *} \\
(0.013)\end{array}$ & $\begin{array}{l}0.015 \\
(0.014)\end{array}$ & $\begin{array}{l}0.037^{* * *} \\
(0.013)\end{array}$ & $\begin{array}{l}0.010 \\
(0.014)\end{array}$ & $\begin{array}{l}0.037^{* * *} \\
(0.012)\end{array}$ & $\begin{array}{l}0.009 \\
(0.014)\end{array}$ & 0.045 \\
\hline Agreeableness & $\begin{array}{l}0.021^{* *} \\
(0.009)\end{array}$ & $\begin{array}{l}-0.030^{* *} \\
(0.013)\end{array}$ & $\begin{array}{l}0.020^{* *} \\
(0.009)\end{array}$ & $\begin{array}{l}-0.028^{* *} \\
(0.013)\end{array}$ & $\begin{array}{l}0.019^{* *} \\
(0.009)\end{array}$ & $\begin{array}{l}-0.029^{* *} \\
(0.014)\end{array}$ & 0.004 \\
\hline Neuroticism & $\begin{array}{l}0.020^{* *} \\
(0.009)\end{array}$ & $\begin{array}{l}-0.003 \\
(0.013)\end{array}$ & $\begin{array}{l}0.012 \\
(0.009)\end{array}$ & $\begin{array}{l}-0.009 \\
(0.014)\end{array}$ & $\begin{array}{l}0.019^{* *} \\
(0.009)\end{array}$ & $\begin{array}{l}-0.011 \\
(0.014)\end{array}$ & 0.071 \\
\hline Risk Aversion & & & $\begin{array}{l}0.014 \\
(0.009)\end{array}$ & $\begin{array}{l}0.005 \\
(0.013)\end{array}$ & $\begin{array}{l}0.012 \\
(0.009)\end{array}$ & $\begin{array}{l}0.000 \\
(0.013)\end{array}$ & 0.448 \\
\hline Years of Education & & & $\begin{array}{l}-0.017^{* * *} \\
(0.004)\end{array}$ & $\begin{array}{l}-0.015^{* * *} \\
(0.005)\end{array}$ & $\begin{array}{l}-0.016^{* * *} \\
(0.004)\end{array}$ & $\begin{array}{l}-0.013^{* * *} \\
(0.005)\end{array}$ & 0.639 \\
\hline German Ethnicity $^{d}$ & & & & & $\begin{array}{l}-0.103^{* * *} \\
(0.016)\end{array}$ & $\begin{array}{l}-0.138^{* * *} \\
(0.039)\end{array}$ & 0.406 \\
\hline East Germany ${ }^{d}$ & & & & & $\begin{array}{l}0.034 \\
(0.022)\end{array}$ & $\begin{array}{l}0.101^{* * *} \\
(0.031)\end{array}$ & 0.078 \\
\hline Religious Affiliation ${ }^{d}$ & & & & & $\begin{array}{l}0.022 \\
(0.019)\end{array}$ & $\begin{array}{l}0.085^{* * *} \\
(0.029)\end{array}$ & 0.069 \\
\hline Observations & 3642 & 3469 & 3642 & 3469 & 3642 & 3469 & \\
\hline
\end{tabular}

Probit Model-Average Marginal Effects.

Note: Numbers in ( ) are robust standard errors. Model also includes age in 2005.

${ }^{d}$ : marginal effect for discrete change of dummy variable from 0 to 1 .

${ }^{*}=\mathrm{p}<0.1,{ }^{* *}=\mathrm{p}<0.05,{ }^{* * *}=\mathrm{p}<0.01$.

agreeableness), reversing the pattern for women. Education and German ethnicity reduce marriage probabilities for both men and women, and men in the East German sample (and those with a religious affiliation) are more likely to marry. Schmidt (2008) and Spivey (2010) found that risk aversion was positively related to the timing of transitions to marriage in U.S. data, but there is no significant effect of risk aversion on marriage by age 35 in these data after controlling for personality.

Tables 4 and 5 report marginal effects for the same models run separately for men and women in the older birth cohorts (1945-1959) and the younger cohorts (1960-1970). Some clear patterns emerge. In Table 4, we can see that the effects of individual personality traits on the marriage probabilities of older cohorts of men and women are quite distinct, as predicted by the production complementarities model of marital surplus. Extraversion significantly increases the probability of marriage for both men and women, but there the similarities end. Conscientiousness increases the probability of marriage by age 35 for men but not for women, and the difference is statistically significant. Agreeableness is significant for both, but with opposite signs-agreeable women and antagonistic men are more likely to marry. In other studies (and in this sample as well) antagonism and conscientiousness are predictive of higher earnings (Nyhus and Pons, Mueller and Plug, Heineck and Anger), so that these effects on selection into marriage, combined with the selection of agreeable women, is consistent with traditionally specialized production in marriage. 
Table 4 The probability of marriage by age 35: old cohorts

\begin{tabular}{|c|c|c|c|c|c|c|c|}
\hline & Women & Men & Women & Men & Women & Men & $\beta_{\mathrm{m}} \neq \beta_{\mathrm{f}}$ \\
\hline & 1 & 2 & 3 & 4 & 5 & 6 & (p-value) \\
\hline \multicolumn{8}{|l|}{$\begin{array}{l}\text { "Big 5" Personality } \\
\text { Traits }\end{array}$} \\
\hline $\begin{array}{l}\text { Openness to } \\
\text { Experience }\end{array}$ & $\begin{array}{l}-0.018^{*} \\
(0.010)\end{array}$ & $\begin{array}{l}-0.026 \\
(0.018)\end{array}$ & $\begin{array}{l}-0.005 \\
(0.010)\end{array}$ & $\begin{array}{l}-0.021 \\
(0.019)\end{array}$ & $\begin{array}{l}-0.003 \\
(0.010)\end{array}$ & $\begin{array}{l}-0.020 \\
(0.019)\end{array}$ & 0.428 \\
\hline Conscientiousness & $\begin{array}{l}0.012 \\
(0.012)\end{array}$ & $\begin{array}{l}0.046^{* * *} \\
(0.015)\end{array}$ & $\begin{array}{l}0.008 \\
(0.012)\end{array}$ & $\begin{array}{l}0.042^{* * *} \\
(0.016)\end{array}$ & $\begin{array}{l}0.007 \\
(0.011)\end{array}$ & $\begin{array}{l}0.041^{* *} \\
(0.016)\end{array}$ & 0.080 \\
\hline Extraversion & $\begin{array}{l}0.039^{* *} \\
(0.016)\end{array}$ & $\begin{array}{l}0.032^{*} \\
(0.017)\end{array}$ & $\begin{array}{l}0.035^{* *} \\
(0.015)\end{array}$ & $\begin{array}{l}0.026^{*} \\
(0.016)\end{array}$ & $\begin{array}{l}0.032^{* *} \\
(0.014)\end{array}$ & $\begin{array}{l}0.028^{*} \\
(0.016)\end{array}$ & 0.851 \\
\hline Agreeableness & $\begin{array}{l}0.017 \\
(0.011)\end{array}$ & $\begin{array}{l}-0.049^{* * *} \\
(0.016)\end{array}$ & $\begin{array}{l}0.018^{*} \\
(0.010)\end{array}$ & $\begin{array}{l}-0.048^{* * *} \\
(0.017)\end{array}$ & $\begin{array}{l}0.018^{*} \\
(0.010)\end{array}$ & $\begin{array}{l}-0.049^{* * *} \\
(0.016)\end{array}$ & 0.000 \\
\hline Neuroticism & $\begin{array}{l}0.015 \\
(0.010)\end{array}$ & $\begin{array}{l}0.008 \\
(0.017)\end{array}$ & $\begin{array}{l}0.011 \\
(0.010)\end{array}$ & $\begin{array}{l}0.006 \\
(0.017)\end{array}$ & $\begin{array}{l}0.011 \\
(0.009)\end{array}$ & $\begin{array}{l}0.004 \\
(0.017)\end{array}$ & 0.716 \\
\hline Risk Aversion & & & $\begin{array}{l}0.003 \\
(0.012)\end{array}$ & $\begin{array}{l}-0.004 \\
(0.017)\end{array}$ & $\begin{array}{l}0.002 \\
(0.011)\end{array}$ & $\begin{array}{l}-0.007 \\
(0.017)\end{array}$ & 0.657 \\
\hline Years of Education & & & $\begin{array}{l}-0.016^{* * *} \\
(0.004)\end{array}$ & $\begin{array}{l}-0.011^{*} \\
(0.006)\end{array}$ & $\begin{array}{l}-0.015^{* * *} \\
(0.004)\end{array}$ & $\begin{array}{l}-0.010 \\
(0.006)\end{array}$ & 0.488 \\
\hline German Ethnicity $^{d}$ & & & & & $\begin{array}{l}-0.076^{* * *} \\
(0.014)\end{array}$ & $\begin{array}{l}-0.095^{*} \\
(0.054)\end{array}$ & 0.733 \\
\hline East Germany ${ }^{d}$ & & & & & $\begin{array}{l}0.047^{* *} \\
(0.018)\end{array}$ & $\begin{array}{l}0.095^{* * *} \\
(0.034)\end{array}$ & 0.212 \\
\hline Religious Affiliation ${ }^{d}$ & & & & & $\begin{array}{l}-0.012 \\
(0.020)\end{array}$ & $\begin{array}{l}0.068^{*} \\
(0.036)\end{array}$ & 0.052 \\
\hline Observations & 1830 & 1735 & 1830 & 1735 & 1830 & 1735 & \\
\hline
\end{tabular}

Probit Model-Average Marginal Effects.

Note: Numbers in ( ) are robust standard errors. Model also includes age in 2005.

$\mathrm{d}_{\text {: }}$ marginal effect for discrete change of dummy variable from 0 to 1 .

${ }^{*}=\mathrm{p}<0.1,{ }^{* *}=\mathrm{p}<0.05,{ }^{* * *}=\mathrm{p}<0.01$.

The inclusion of risk aversion and demographic variables in the marriage equation does not substantially alter these conclusions.

In summary, men in the older cohort who marry by age 35 have a trait profile that is related to earnings power rather than interpersonal connection, compared to unmarried men. Combined with the selection of nurturing and sociable women into marriage, these results are suggestive of continued specialization in the generation of marital surplus for post-war cohorts in Germany, with women making emotional and social contributions and men, material ones. Since we do not have pre-marriage measures of personality, a strong causal interpretation of these results would be inappropriate; if personality is somewhat malleable, then these associations may also reflect an adaptation to social roles.

Table 5 repeats these analyses for the young cohorts born between 1960 and 1970. The personality coefficients for men and women are very similar (and, in fact, are not significantly different from each other except for extraversion, which increases marriage probabilities for women but not for men). Openness to experience has a large negative effect on marriage probabilities, especially for women, and conscientiousness has a strong positive effect on both. These results indicate that a willingness to commit to a conventional long-term arrangement has become an important factor in the marriage decisions of both sexes. The effects of personality are generally robust across specifications, though the effect of openness on marriage for men just fails to reach conventional significance levels 
Table 5 The probability of marriage by age 35: young cohorts

\begin{tabular}{|c|c|c|c|c|c|c|c|}
\hline & Women & Men & Women & Men & Women & Men & $\beta_{\mathrm{m}} \neq \beta_{\mathrm{f}}$ \\
\hline & 1 & 2 & 3 & 4 & 5 & 6 & (p-value) \\
\hline \multicolumn{8}{|l|}{$\begin{array}{l}\text { "Big 5" Personality } \\
\text { Traits }\end{array}$} \\
\hline $\begin{array}{l}\text { Openness to } \\
\text { Experience }\end{array}$ & $\begin{array}{l}-0.073^{* * *} \\
(0.017)\end{array}$ & $\begin{array}{l}-0.044^{* *} \\
(0.020)\end{array}$ & $\begin{array}{l}-0.061^{* * *} \\
(0.017)\end{array}$ & $\begin{array}{l}-0.035^{*} \\
(0.021)\end{array}$ & $\begin{array}{l}-0.063^{* * *} \\
(0.017)\end{array}$ & $\begin{array}{l}-0.034 \\
(0.021)\end{array}$ & 0.283 \\
\hline Conscientiousness & $\begin{array}{l}0.056^{* * *} \\
(0.015)\end{array}$ & $\begin{array}{l}0.062^{* * *} \\
(0.019)\end{array}$ & $\begin{array}{l}0.052^{* * *} \\
(0.015)\end{array}$ & $\begin{array}{l}0.056^{* * *} \\
(0.019)\end{array}$ & $\begin{array}{l}0.049^{* * *} \\
(0.014)\end{array}$ & $\begin{array}{l}0.055^{* * *} \\
(0.019)\end{array}$ & 0.799 \\
\hline Extraversion & $\begin{array}{l}0.032^{*} \\
(0.017)\end{array}$ & $\begin{array}{l}0.001 \\
(0.021)\end{array}$ & $\begin{array}{l}0.035^{* *} \\
(0.017)\end{array}$ & $\begin{array}{l}-0.004 \\
(0.022)\end{array}$ & $\begin{array}{l}0.039^{* *} \\
(0.016)\end{array}$ & $\begin{array}{l}-0.006 \\
(0.022)\end{array}$ & 0.098 \\
\hline Agreeableness & $\begin{array}{l}0.026^{*} \\
(0.015)\end{array}$ & $\begin{array}{l}-0.013 \\
(0.019)\end{array}$ & $\begin{array}{l}0.023 \\
(0.015)\end{array}$ & $\begin{array}{l}-0.010 \\
(0.020)\end{array}$ & $\begin{array}{l}0.022 \\
(0.014)\end{array}$ & $\begin{array}{l}-0.009 \\
(0.020)\end{array}$ & 0.204 \\
\hline Neuroticism & $\begin{array}{l}0.026^{*} \\
(0.015)\end{array}$ & $\begin{array}{l}-0.016 \\
(0.020)\end{array}$ & $\begin{array}{l}0.016 \\
(0.015)\end{array}$ & $\begin{array}{l}-0.027 \\
(0.021)\end{array}$ & $\begin{array}{l}0.016 \\
(0.015)\end{array}$ & $\begin{array}{l}-0.029 \\
(0.020)\end{array}$ & 0.072 \\
\hline Risk Aversion & & & $\begin{array}{l}0.029^{* *} \\
(0.014)\end{array}$ & $\begin{array}{l}0.012 \\
(0.019)\end{array}$ & $\begin{array}{l}0.027^{*} \\
(0.014)\end{array}$ & $\begin{array}{l}0.005 \\
(0.018)\end{array}$ & 0.335 \\
\hline Years of Education & & & $\begin{array}{l}-0.019^{* * *} \\
(0.006)\end{array}$ & $\begin{array}{l}-0.020^{* * *} \\
(0.007)\end{array}$ & $\begin{array}{l}-0.017^{* * *} \\
(0.005)\end{array}$ & $\begin{array}{l}-0.018^{* *} \\
(0.007)\end{array}$ & 0.907 \\
\hline German Ethnicity ${ }^{d}$ & & & & & $\begin{array}{l}-0.136^{* * *} \\
(0.029)\end{array}$ & $\begin{array}{l}-0.191^{* * *} \\
(0.055)\end{array}$ & 0.376 \\
\hline East Germany ${ }^{d}$ & & & & & $\begin{array}{l}0.012 \\
(0.043)\end{array}$ & $\begin{array}{l}0.107^{* *} \\
(0.050)\end{array}$ & 0.150 \\
\hline Religious Affiliation ${ }^{d}$ & & & & & $\begin{array}{l}0.059^{*} \\
(0.033)\end{array}$ & $\begin{array}{l}0.099^{* *} \\
(0.043)\end{array}$ & 0.461 \\
\hline Observations & 1812 & 1734 & 1812 & 1734 & 1812 & 1734 & \\
\hline
\end{tabular}

Probit Model-Average Marginal Effects.

Note: Numbers in ( ) are robust standard errors. Model also includes age in 2005.

$\mathrm{d}$ : marginal effect for discrete change of dummy variable from 0 to 1 .

${ }^{*}=\mathrm{p}<0.1,{ }^{* *}=\mathrm{p}<0.05,{ }^{* * *}=\mathrm{p}<0.01$.

once religious affiliation is included. ${ }^{14}$ The consistency of the associations between personality and marriage selection for men and women suggests that they are reflective of shared preferences for stable and conventional domestic arrangements.

\subsection{Divorce}

In Table 6, the hazard ratios for a Cox proportional hazards model of time to divorce for first marriages are reported for the full sample. The most notable result is the very large positive association between openness to experience and the probability that a first marriage ends in divorce for both men and women. The finding that openness, which is associated with a desire for variety and change, appears to be a significant detriment to a stable marital arrangement suggests a re-interpretation of the "surprise" model of divorce. That individuals have a taste for variety is a commonplace assumption, and the demand for variety in other spheres has been shown to be associated with income and education (Behrman and Deolalikar, 1989; Gronau and Hamermesh, 2008). In intimate partnerships, it appears that a taste for variety may be destabilizing.

For men, openness is positively related (and conscientiousness is negatively related) to the probability of divorce. The conscientiousness result is consistent with the positive association of this trait with marriage for men, and with an 
Table 6 Divorce hazard ratios for first marriages-full sample

\begin{tabular}{|c|c|c|c|c|c|c|c|}
\hline & Women & Men & Women & Men & Women & Men & $\beta_{\mathrm{m}} \neq \beta_{\mathrm{f}}$ \\
\hline & 1 & 2 & 3 & 4 & 5 & 6 & (p-value) \\
\hline \multicolumn{8}{|l|}{$\begin{array}{l}\text { "Big 5" Personality } \\
\text { Traits }\end{array}$} \\
\hline $\begin{array}{l}\text { Openness to } \\
\text { Experience }\end{array}$ & $\begin{array}{l}1.142^{* *} \\
(0.067)\end{array}$ & $\begin{array}{l}1.227^{* * *} \\
(0.070)\end{array}$ & $\begin{array}{l}1.121^{*} \\
(0.068)\end{array}$ & $\begin{array}{l}1.232^{* * *} \\
(0.071)\end{array}$ & $\begin{array}{l}1.129^{* *} \\
(0.069)\end{array}$ & $\begin{array}{l}1.215^{* * *} \\
(0.069)\end{array}$ & 0.378 \\
\hline Conscientiousness & $\begin{array}{l}1.079 \\
(0.067)\end{array}$ & $\begin{array}{l}0.837^{* * *} \\
(0.052)\end{array}$ & $\begin{array}{l}1.075 \\
(0.067)\end{array}$ & $\begin{array}{l}0.831^{* * *} \\
(0.052)\end{array}$ & $\begin{array}{l}1.073 \\
(0.068)\end{array}$ & $\begin{array}{l}0.828^{* * *} \\
(0.051)\end{array}$ & 0.004 \\
\hline Extraversion & $\begin{array}{l}1.068 \\
(0.060)\end{array}$ & $\begin{array}{l}1.159^{* *} \\
(0.079)\end{array}$ & $\begin{array}{l}1.035 \\
(0.058)\end{array}$ & $\begin{array}{l}1.132^{*} \\
(0.076)\end{array}$ & $\begin{array}{l}1.003 \\
(0.056)\end{array}$ & $\begin{array}{l}1.127^{*} \\
(0.075)\end{array}$ & 0.185 \\
\hline Agreeableness & $\begin{array}{l}0.925 \\
(0.050)\end{array}$ & $\begin{array}{l}0.996 \\
(0.070)\end{array}$ & $\begin{array}{l}0.946 \\
(0.052)\end{array}$ & $\begin{array}{l}1.006 \\
(0.072)\end{array}$ & $\begin{array}{l}0.950 \\
(0.052)\end{array}$ & $\begin{array}{l}1.015 \\
(0.072)\end{array}$ & 0.464 \\
\hline Neuroticism & $\begin{array}{l}1.106^{*} \\
(0.059)\end{array}$ & $\begin{array}{l}1.010 \\
(0.056)\end{array}$ & $\begin{array}{l}1.122^{* *} \\
(0.058)\end{array}$ & $\begin{array}{l}1.000 \\
(0.056)\end{array}$ & $\begin{array}{l}1.121^{* *} \\
(0.057)\end{array}$ & $\begin{array}{l}1.011 \\
(0.055)\end{array}$ & 0.165 \\
\hline Risk Aversion & & & $\begin{array}{l}0.826^{* * *} \\
(0.046)\end{array}$ & $\begin{array}{l}0.918 \\
(0.059)\end{array}$ & $\begin{array}{l}0.852^{* * *} \\
(0.050)\end{array}$ & $\begin{array}{l}0.951 \\
(0.063)\end{array}$ & 0.876 \\
\hline Years of Education & & & $\begin{array}{l}1.000 \\
(0.022)\end{array}$ & $\begin{array}{l}0.956^{*} \\
(0.023)\end{array}$ & $\begin{array}{l}0.975 \\
(0.023)\end{array}$ & $\begin{array}{l}0.939^{* *} \\
(0.023)\end{array}$ & 0.876 \\
\hline German Ethnicity & & & & & $\begin{array}{l}1.787^{* *} \\
(0.448)\end{array}$ & $\begin{array}{l}2.401^{* * *} \\
(0.747)\end{array}$ & 0.481 \\
\hline East Germany & & & & & $\begin{array}{l}0.834 \\
(0.127)\end{array}$ & $\begin{array}{l}0.964 \\
(0.150)\end{array}$ & 0.508 \\
\hline Religious Affiliation & & & & & $\begin{array}{l}0.529^{* * *} \\
(0.060)\end{array}$ & $\begin{array}{l}0.540^{* * *} \\
(0.068)\end{array}$ & 0.903 \\
\hline Observations & 3362 & 3044 & 3362 & 3044 & 3362 & 3044 & \\
\hline
\end{tabular}

Cox proportional hazard model-Hazard ratios.

Note: Numbers in ( ) are robust standard errors. Model also includes age at first marriage and year of marriage. ${ }^{*}=p<0.1,{ }^{* *}=p<0.05,{ }^{* * *}=p<0.01$.

interpretation that male conscientiousness increases marital surplus. However, the divorce models are not in general strictly reversals of the marriage results-the positive coefficient of male extraversion is consistent with this trait increasing the productivity of searching for partners, thus increasing both marriage and divorce probabilities.

Hazard models of divorce for the older cohorts of men (Table 7) yield results that are very similar to those for the full sample-extraversion and openness are strongly positively related to divorce, and conscientiousness is negatively related. For women in the older cohorts, the effect of agreeableness on divorce is negative, and the effect of neuroticism is positive. Once again, these results are not consistent with a simple lowmarital-surplus story about divorce, since neuroticism had no significant effects on marriage. Neuroticism/emotionality may have a negative influence on problem-solving within marriage or on renegotiations following a shock.

For the younger cohorts (Table 8) there are no significant effects of personality on divorce, except a negative coefficient of conscientiousness for men, and few significant effects of demographic variables as well. A possible explanation for this is that we observe, on average, only the first 13 to 15 years of marriage for individuals in the younger cohort. Risk aversion decreases the divorce hazard for women in both cohorts. Light and Ahn (2010) find that risk tolerance has a positive effect on the probability of divorce for both men and women in U.S. data, though the 
Table 7 Divorce hazard ratios for first marriages-old cohorts

\begin{tabular}{|c|c|c|c|c|c|c|c|}
\hline & Women & Men & Women & Men & Women & Men & $\beta_{\mathrm{m}} \neq \beta_{\mathrm{f}}$ \\
\hline & 1 & 2 & 3 & 4 & 5 & 6 & (p-value) \\
\hline \multicolumn{8}{|l|}{$\begin{array}{l}\text { "Big 5" Personality } \\
\text { Trait }\end{array}$} \\
\hline $\begin{array}{l}\text { Openness to } \\
\text { Experience }\end{array}$ & $\begin{array}{l}1.190^{* *} \\
(0.092)\end{array}$ & $\begin{array}{l}1.271^{* * *} \\
(0.090)\end{array}$ & $\begin{array}{l}1.146^{*} \\
(0.088)\end{array}$ & $\begin{array}{l}1.259^{* * *} \\
(0.088)\end{array}$ & $\begin{array}{l}1.184^{* *} \\
(0.091)\end{array}$ & $\begin{array}{l}1.238^{* * *} \\
(0.087)\end{array}$ & 0.668 \\
\hline Conscientiousness & $\begin{array}{l}1.081 \\
(0.083)\end{array}$ & $\begin{array}{l}0.886 \\
(0.071)\end{array}$ & $\begin{array}{l}1.083 \\
(0.083)\end{array}$ & $\begin{array}{l}0.874^{*} \\
(0.068)\end{array}$ & $\begin{array}{l}1.058 \\
(0.080)\end{array}$ & $\begin{array}{l}0.860^{*} \\
(0.068)\end{array}$ & 0.059 \\
\hline Extraversion & $\begin{array}{l}1.083 \\
(0.082)\end{array}$ & $\begin{array}{l}1.171^{* *} \\
(0.088)\end{array}$ & $\begin{array}{l}1.054 \\
(0.080)\end{array}$ & $\begin{array}{l}1.142^{*} \\
(0.084)\end{array}$ & $\begin{array}{l}1.005 \\
(0.075)\end{array}$ & $\begin{array}{l}1.135^{*} \\
(0.084)\end{array}$ & 0.248 \\
\hline Agreeableness & $\begin{array}{l}0.859^{* *} \\
(0.059)\end{array}$ & $\begin{array}{l}0.981 \\
(0.083)\end{array}$ & $\begin{array}{l}0.873^{* *} \\
(0.060)\end{array}$ & $\begin{array}{l}0.999 \\
(0.083)\end{array}$ & $\begin{array}{l}0.873^{* *} \\
(0.060)\end{array}$ & $\begin{array}{l}1.025 \\
(0.086)\end{array}$ & 0.147 \\
\hline Neuroticism & $\begin{array}{l}1.122^{*} \\
(0.074)\end{array}$ & $\begin{array}{l}0.930 \\
(0.064)\end{array}$ & $\begin{array}{l}1.153^{* *} \\
(0.074)\end{array}$ & $\begin{array}{l}0.921 \\
(0.063)\end{array}$ & $\begin{array}{l}1.151^{* *} \\
(0.071)\end{array}$ & $\begin{array}{l}0.941 \\
(0.065)\end{array}$ & 0.029 \\
\hline Risk Aversion & & & $\begin{array}{l}0.817^{* * *} \\
(0.051)\end{array}$ & $\begin{array}{l}0.859^{* *} \\
(0.065)\end{array}$ & $\begin{array}{l}0.855^{* *} \\
(0.055)\end{array}$ & $\begin{array}{l}0.880 \\
(0.069)\end{array}$ & 0.777 \\
\hline Years of Education & & & $\begin{array}{l}1.042^{*} \\
(0.025)\end{array}$ & $\begin{array}{l}0.944^{* *} \\
(0.027)\end{array}$ & $\begin{array}{l}1.002 \\
(0.027)\end{array}$ & $\begin{array}{l}0.930^{* *} \\
(0.027)\end{array}$ & 0.059 \\
\hline German Ethnicity & & & & & $\begin{array}{l}1.732^{*} \\
(0.525)\end{array}$ & $\begin{array}{l}2.056 \\
(0.968)\end{array}$ & 0.769 \\
\hline East Germany & & & & & $\begin{array}{l}0.851 \\
(0.162)\end{array}$ & $\begin{array}{l}0.906 \\
(0.169)\end{array}$ & 0.814 \\
\hline Religious Affiliation & & & & & $\begin{array}{l}0.454^{* * *} \\
(0.061)\end{array}$ & $\begin{array}{l}0.489^{* * *} \\
(0.072)\end{array}$ & 0.711 \\
\hline Observations & 1757 & 1622 & 1757 & 1622 & 1757 & 1622 & \\
\hline
\end{tabular}

Cox proportional hazard model-Hazard Ratios.

Note: Numbers in ( ) are robust standard errors. Model also includes age at first marriage and year of marriage. ${ }^{*}=p<0.1,{ }^{* *}=p<0.05,{ }^{* * *}=p<0.01$.

effect for women was consistently larger than the effect for men-a result they attribute to the greater income risk that divorce entails for women.

The dissolution of a first marriage or cohabitation appears to be related to three factors that are influenced by personality and other psychological traits: low marital surplus (openness, male conscientiousness, female agreeableness), emotional stability/positive affect (neuroticism), and the arrival and assessment of alternatives (extraversion). Emotional stability seems to be particularly salient for women, and the availability of alternatives (or willingness to seek them) for men.

\section{Conclusions}

Evidence from the German Socio-economic Panel Study shows that several dimensions of personality are strongly associated with the propensity of men and women to marry and to divorce. For younger cohorts, born between 1960 and 1970, two personality traits (openness to experience and conscientiousness) have significant effects (in most specifications) on the probability that men and women marry by age 35. This is consistent with a model in which marital surplus depends on the joint consumption of public goods, and these personality traits appear to be associated with high demand for marital public goods. For older cohorts, born between 1945 and 1959, psychological traits have gender-distinct effects on marriage that are consistent with specialized production of marital services, with agreeable women, and conscientious, antagonistic men more likely to marry. 
Table 8 Divorce hazard ratios for first marriages-young cohorts

\begin{tabular}{|c|c|c|c|c|c|c|c|}
\hline & Women & Men & Women & Men & Women & Men & $\beta_{\mathrm{m}} \neq \beta_{\mathrm{f}}$ \\
\hline & 1 & 2 & 3 & 4 & 5 & 6 & (p-value) \\
\hline \multicolumn{8}{|l|}{$\begin{array}{l}\text { "Big 5" Personality } \\
\text { Traits }\end{array}$} \\
\hline $\begin{array}{l}\text { Openness to } \\
\text { Experience }\end{array}$ & $\begin{array}{l}1.100 \\
(0.095)\end{array}$ & $\begin{array}{l}1.172^{*} \\
(0.106)\end{array}$ & $\begin{array}{l}1.099 \\
(0.100)\end{array}$ & $\begin{array}{l}1.182^{*} \\
(0.108)\end{array}$ & $\begin{array}{l}1.094 \\
(0.102)\end{array}$ & $\begin{array}{l}1.151 \\
(0.102)\end{array}$ & 0.693 \\
\hline Conscientiousness & $\begin{array}{l}1.070 \\
(0.104)\end{array}$ & $\begin{array}{l}0.788^{* *} \\
(0.076)\end{array}$ & $\begin{array}{l}1.056 \\
(0.105)\end{array}$ & $\begin{array}{l}0.786^{* *} \\
(0.075)\end{array}$ & $\begin{array}{l}1.071 \\
(0.108)\end{array}$ & $\begin{array}{l}0.801^{* *} \\
(0.075)\end{array}$ & 0.040 \\
\hline Extraversion & $\begin{array}{l}1.041 \\
(0.082)\end{array}$ & $\begin{array}{l}1.164 \\
(0.132)\end{array}$ & $\begin{array}{l}0.997 \\
(0.082)\end{array}$ & $\begin{array}{l}1.160 \\
(0.131)\end{array}$ & $\begin{array}{l}0.985 \\
(0.081)\end{array}$ & $\begin{array}{l}1.147 \\
(0.124)\end{array}$ & 0.274 \\
\hline Agreeableness & $\begin{array}{l}1.026 \\
(0.083)\end{array}$ & $\begin{array}{l}1.024 \\
(0.124)\end{array}$ & $\begin{array}{l}1.059 \\
(0.088)\end{array}$ & $\begin{array}{l}1.022 \\
(0.130)\end{array}$ & $\begin{array}{l}1.066 \\
(0.088)\end{array}$ & $\begin{array}{l}1.015 \\
(0.128)\end{array}$ & 0.705 \\
\hline Neuroticism & $\begin{array}{l}1.078 \\
(0.091)\end{array}$ & $\begin{array}{l}1.141 \\
(0.105)\end{array}$ & $\begin{array}{l}1.078 \\
(0.089)\end{array}$ & $\begin{array}{l}1.130 \\
(0.104)\end{array}$ & $\begin{array}{l}1.084 \\
(0.090)\end{array}$ & $\begin{array}{l}1.121 \\
(0.102)\end{array}$ & 0.786 \\
\hline Risk Aversion & & & $\begin{array}{l}0.828^{* *} \\
(0.079)\end{array}$ & $\begin{array}{l}1.024 \\
(0.110)\end{array}$ & $\begin{array}{l}0.845^{*} \\
(0.082)\end{array}$ & $\begin{array}{l}1.067 \\
(0.120)\end{array}$ & 0.127 \\
\hline Years of Education & & & $\begin{array}{l}0.939 \\
(0.036)\end{array}$ & $\begin{array}{l}0.979 \\
(0.037)\end{array}$ & $\begin{array}{l}0.930^{*} \\
(0.037)\end{array}$ & $\begin{array}{l}0.958 \\
(0.039)\end{array}$ & 0.602 \\
\hline German Ethnicity & & & & & $\begin{array}{l}1.668 \\
(0.639)\end{array}$ & $\begin{array}{l}3.185^{* * *} \\
(1.213)\end{array}$ & 0.269 \\
\hline East Germany & & & & & $\begin{array}{l}0.780 \\
(0.191)\end{array}$ & $\begin{array}{l}1.095 \\
(0.274)\end{array}$ & 0.346 \\
\hline Religious Affiliation & & & & & $\begin{array}{l}0.630^{* *} \\
(0.117)\end{array}$ & $\begin{array}{l}0.636^{* *} \\
(0.144)\end{array}$ & 0.974 \\
\hline Observations & 1605 & 1422 & 1605 & 1422 & 1605 & 1422 & \\
\hline
\end{tabular}

Cox proportional hazard model-Hazard Ratios.

Note: Numbers in ( ) are robust standard errors. Model also includes age at first marriage and year of marriage. ${ }^{*}=p<0.1,{ }^{* *}=p<0.05,{ }^{* * *}=p<0.01$.

Openness to experience, which reflects a desire for variety and change as well as imagination and creativity, is strongly related to both long-term singlehood for women and to divorce for both men and women. The divorce models indicate that, with a few exceptions, traits expected to contribute to marital surplus, based on the marriage models, also inhibit divorce. There is some evidence that divorce may also be driven by difficulties in problem-solving or negotiation, including a positive effect of neuroticism and antagonism for older women. More notable are effects that seem consistent with the positive impact of openness to experience and suggest that a willingness to consider and seek out alternatives may increase the risk of divorce-the positive effects of female risk tolerance and of male extraversion.

For the older cohorts, the determinants of marriage for men and women include some distinct differences that suggest marital surplus is related to nurturance by women and to men's stability and earnings. This pattern is consistent with the relatively conservative social environment in Germany, and with the persistence of traditional gender roles reflected in the slow movement of women into the paid workforce in this country. However, the marriage models for younger cohorts indicate a pronounced change in the selection of men and women into marriage and cohabitation, with high levels of conscientiousness and low openness increasing the attractiveness of stable domestic partnerships for both sexes.

In general, these results indicate that personality traits measure aspects of individual preferences and capabilities that are important in generating positive returns 
to an intimate partnership such as marriage, and in maintaining marital stability. Further, the distinctly different patterns of selection by personality into marriage and divorce between older and younger cohorts of the German population are consistent with a rapid change in the nature of marriage-from an institution in which gender-specialized production and exchange is an important source of marital surplus to one in which the joint consumption of family public goods is paramount.

\section{Endnotes}

${ }^{1}$ Throughout the paper, "marriage" and "marital surplus" will refer to both legal marriage and cohabitation.

2 Psychological traits are often labeled "non-cognitive skills" in these studies to acknowledge their labor market returns and to distinguish them from IQ and other measures of cognitive ability.

${ }^{3}$ For a treatment of marital decisions with imperfect commitment, see Lundberg and Pollak (2003).

${ }^{4}$ Mueller and Plug (2006) find that antagonism and emotional stability increase men's earnings, while conscientiousness and openness increase women's. Heineck and Anger (2010) examine the effects of cognitive abilities and psychological traits (including positive and negative reciprocity and locus of control as well as personality) on earnings in Germany and find that, though the effects of personality on men's and women's earnings are not uniform, both experience a wage penalty for an external locus of control. Heineck (2011) finds wage penalties for neuroticism and agreeableness for both male and female workers in the U.K. Using Dutch data, Nyhus and Pons (2005) find that emotional stability is positively related to the wages of men and women, while agreeableness is associated with lower wages for women. The returns to personality factors vary both by tenure and by educational group, suggesting that different personality traits may enhance productivity in different occupations.

${ }^{5}$ Plotnick (1992) finds that self-esteem and, to a lesser extent, locus of control, affect premarital childbearing in the United States.

${ }^{6}$ Bergstrom and Cornes (1983) show that, with these preferences, the Pareto optimal amount of a public good is independent of the income distribution, and derive the necessary and sufficient conditions for preferences to be of this form. Bergstrom (1989) develops the application of these results to transferable utility in the household.

${ }^{7}$ In these one-period models, the production and consumption benefits of marriage are directly related to coresidence and joint parenthood, and need not require legal marriage. However, a full realization of the gains to specialization and to childrearing relies on a long-term commitment (Lundberg, 2008). For this reason, characteristics that enhance an individual's ability to make credible intertemporal commitments (such as conscientiousness or trustworthiness) and to negotiate effectively may also lead to a higher probability of marriage for both men and women.

${ }^{8}$ Fertility rates fell rapidly in the early 1970s in Germany (from about 2.0 to 1.5 between 1970 and 1975) and have declined only modestly since then, so the younger cohorts would have reached adolescence and made education decisions in 
a very low fertility environment. Overall employment rates for women in West Germany, however, did not begin to increase substantially until the late 1990s (female participation rates in East Germany were substantially higher), so even the younger cohorts reached adulthood facing a labor market in which maternal labor supply was very low.

${ }^{9}$ There is considerable evidence of some systematic changes in personality traits with age-conscientiousness increases and extraversion decreases with age, for example. We cannot separate age and cohort effects, but the age pattern in the mean raw scores for men and women age 18 to 64 in SOEP 2005 is similar to that found in other studies.

${ }^{10}$ The life events included in the study by Magnus et al. (1993) included marriage and divorce/separation, but their analysis of causality between personality and experiences aggregated a large number of positive and negative events.

${ }^{11}$ Caspi and Herbener (1990) argue that this stability may be endogenous: individuals choose situations compatible with their dispositions, such as assortative mating, and therefore maintain considerable personality stability over a lifetime.

${ }^{12}$ However, Jokela et al. find that having children increased levels of emotionality, particularly in participants with high baseline emotionality, over the nine years of the longitudinal Finnish study discussed above.

${ }^{13}$ Inclusion in the East German sample is an imperfect proxy for socialization (and, for the older cohorts, the experience of family life) if the very different economic and social environment of East Germany before reunification in 1989.

${ }^{14}$ An earlier version of this paper (Lundberg, 2010) reported models in which openness remained significant in the male marriage models for the younger cohort. The minor discrepancies between these versions of the empirical results are due to changes in sampling (the small guestworker sample was excluded in the earlier version, and this version uses a consistent sample with non-missing variables for all models).

Competing interests

The IZA Journal of Labor Economics is committed to the IZA Guiding Principles of Research Integrity. The author declares that he has observed these principles.

\section{Acknowledgments}

Comments from participants in the "Household Economics" session at the 2008 European Society for Population Economics annual conference in London, the Gender Economics seminar at Université Paris 1 Panthéon-Sorbonne, the Population Association of American 2010 Meetings and seminars at Barnard College, Columbia University, New York University, CUNY Graduate Center, the University of Washington and Duke University, and from Katharina Spiess, Dick Startz, Simine Vazire and Bill Dickens are gratefully acknowledged. Financial support was provided by the Castor Professorship in Economics. An early version of this paper was completed while I was a Visiting Scholar at the Russell Sage Foundation in New York. Kwok Ping Tsang and Seth Borgo have provided invaluable assistance.

Responsible Editor: Pierre Cahuc

\section{Author details}

${ }^{1}$ Department of Economics and Broom Center for Demography, 2127 North Hall, University of California, Santa Barbara, Santa Barbara, CA 93106-9210, USA. ²Department of Economics, University of Bergen. ${ }^{3}$ IZA, Bonn, Germany.

Received: 11 June 2012 Accepted: 27 June 2012

Published: 9 October 2012

References

Aguiar M, Hurst E (2007) "Measuring Trends in Leisure: the allocation of time over five decades. Quarterly Journal of Economics 122(3):969

Becker A, Deckers T, Dohmen TJ, Falk A, Kosse F (2012) The Relationship between Economic Preferences and Psychological Personality Measures" IZA DP 6470

Becker GS (1981) A Treatise on the Family. Harvard University Press, Cambridge 
Becker GS, Landes EM, Michael RT (1977) An Economic Analysis of Marital Instability. Journal of Political Economy 85 (6):1141-1187

Behrman JR, Deolalikar AB (1989) Is Variety the Spice of Life? Implications for Calorie Intake. The Review of Economics and Statistics 71(4):666-672

Bergstrom TC (1989) A fresh look at the rotten kid theorem-and other household mysteries. Journal of Political Economy 97(5):1138-1159

Bergstrom TC, Cornes RC (1983) Independence of allocative efficiency from distribution in the theory of public goods. Econometrica 51(6):1753-1765

Borghans L, Duckworth AL, Heckman JJ, ter Weel B (2008) The economics and psychology of personality traits. Journal of Human Resources 43(4):972-1059

Caprara GV, Cervone D (2000) Personality: Determinants, Dynamics, and Potentials. Cambridge University Press

Caspi A, Herbener ES (1990) Continuity and change: assortative marriage and the consistency of personality in adulthood. Journal of Personality and Social Psychology 58(2):250-258

Charles KK, Stephens M Jr (2004) Job displacement, disability, and divorce. Journal of Labor Economics 22(2):489-522

Chiswick B, Houseworth C (2011) Ethnic intermarriage among immigrants: human capital and assortative mating. Review of Economics of the Household 9(2):149-180

Costa PT, McCrae RR (1997) Longitudinal Stability of Adult Personality. In: Hogan R, Johnson J, Briggs S (eds) Handbook of Personality Psychology. Academic, San Diego, pp 269-290

Dohmen T, Falk A, Huffman D, Sunde U, Schupp J, Wagner GG (2011) Individual risk attitudes: measurement, determinants, and behavioral consequences. Journal of the European Economic Association 9(3):522-550

Furtado D, Theodoropoulos N (2011) Interethnic marriage: a choice between ethnic and educational similarities. Journal of Population Economics 24(4):1257-1279

Goldberg LR (1981) Language and individual differences: the search for universals in personality lexicons. In: Wheeler L (ed) Review of Personality and Social Psychology, Vol. 2. Beverly Hills, CA, Sage, pp 141-165

Gronau R, Hamermesh DS (2008) The demand for variety: a household production perspective. Review of Economics and Statistics 90(3):562-572

Heineck G (2011) Does it pay to be nice? personality and earnings in the U.K. Industrial and Labor Relations Review 64 (5):1020-1038

Heineck G, Anger S (2010) The returns to cognitive abilities and personality traits in Germany. Labour Economics 17:535-546

Hogan R, Hogan J (2007) Hogan Personality Inventory Manual, 3rd edn. Hogan Assessment Systems, Tulsa, OK

Isen A, Stevenson B (2010) Women's Education and Family Behavior: Trends in Marriage, Divorce and Fertility. In: Shoven J (ed) Demography and the Economy. University of Chicago Press, Chicago

John OP, Srivastava S (1999) The big five trait taxonomy: history, measurement and theoretical. In: Pervin LA, John OP (eds) Handbook of Personality: Theory and Research. The Guilford Press, New York, pp 102-138

Jokela M, Kivimäki M, Elovainio M, Keltikangas-Järvinen L (2009) Personality and having children: a two-way relationship. Journal of Personality and Social Psychology 96(1):128-230

Kiernan K (1986) Teenage marriage and marital breakdown: a longitudinal study. Population Studies 40(1):35-54

Kinnunen U, Rytkonen O, Miettinen N, Pulkkinen L (2000) Personality and marriage: personality characteristics as predictors of marital quality and stability. Psykologia 35(4):332-345

Lam D (1988) Marriage markets and assortative mating with household public goods: theoretical results and empirical implications. Journal of Human Resources 23(4):462-487

Lesthaeghe RJ (2010) The unfolding story of the second demographic transition. Population and Development Review 36(2):211-251

Light A, Ahn T (2010) Divorce as risky behavior. Demography 47(4):895-921

Lowell KE, Conley JJ (1987) Personality and compatibility: a prospective analysis of marital stability and marital satisfaction. Journal of Personality and Social Psychology 52(1):27-40

Lundberg S (2005) Men and islands: dealing with the family in empirical labor economics. Labour Economics 12 (4):591-612

Lundberg S (2008) Gender and Household Decisionmaking. In: Bettio F (ed) Frontiers in Gender Economics. Routledge, New York

Lundberg S (2010) Personality and Marital Surplus., IZA DP 4945

Lundberg S, Pollak RA (2003) Efficiency in marriage. Review of Economics of the Household 1(3):153-167

Lundberg S, Pollak RA (2007) The american family and family economics. Journal of Economic Perspectives 21(2):3-26

Magnus K, Diener E, Fujita F, Pavot W (1993) Extraversion and neuroticism as predictors of objective life events: a longitudinal analysis. Journal of Personality and Social Psychology 65(5):1046-1053

McAdams DP, Pals JL (2006) A new big five: fundamental principles for an integrative science of personality. American Psychologist 61(3):204-217

McCranie EW, Kahan J (1986) Personality and multiple divorces. Journal of Nervous and Mental Disease 174(3):161-164

McKinnish TG (2004) Occupation, sex-integration, and divorce. American Economic Review 94(2):322-325

Mueller G, Plug E (2006) Estimating the effect of personality on male and female earnings. Industrial and Labor Relations Review 60(1):3-22

Nyhus EK, Pons E (2005) The effects of personality on earnings. Journal of Economic Psychology 26(3):363-384

Ozer DJ, Benet-Martinez V (2006) Personality and the prediction of consequential outcomes. Annual Review of Psychology 57:401-421

Peters HE (1986) Marriage and divorce: informational constraints and private contracting. American Economic Review 76(3):437-454

Plotnick R (1992) The effects of attitudes on teenage premarital pregnancy and its resolution. American Sociological Review 57(6):800-811 
Roberts BW, Kuncel NR, Shiner R, Caspi A, Goldberg L (2007) The power of personality: the comparative validity of personality traits, socioeconomic status, and cognitive ability for predicting important life outcomes. Perpectives on Psychological Science 2(4):313-345

Roberts BW, DelVecchio WF (2000) The rank-order consistency of personality traits from childhood to old age: a quantitative review of longitudinal studies. Psychological Bulletin 126(1):3-25

Schmidt L (2008) Risk preferences and the timing of marriage and childbearing. Demography 45(2):439-460

Schwartz CR, Mare RD (2005) Trends in educational assortative marriage from 1940 to 2003. Demography 42(4):621-646 Spivey C (2010) Desperation or desire? the role of risk-aversion in marriage. Economic Inquiry 48(2):499-516

Stevenson B, Wolfers J (2007) Marriage and divorce: changes and their driving forces. Journal of Economic Perspectives 21(2):27-52

Tavares L (2008) Who Delays Childbearing? The Relationship between Fertility, Education and Personality Traits." Dondena Working Paper No. 9., revised January 2010)

Wagner GG, Frick JR, Jürgen S (2007) The german socio-economic panel study (SOEP) - scope, evolution and enhancements. Schmollers Jahrbuch 127(1):139-169

Weiss Y, Willis R (1997) Match quality, new information, and marital dissolution. Journal of Labor Economics 15(S1):S293

Xie Y, Raymo JJ, Goyette KA, Thornton A (2003) Economic potential and entry into marriage and cohabitation. Demography 40(2):351-367

doi:10.1186/ 2193-8997-1-3

Cite this article as: Lundberg: Personality and marital surplus. IZA Journal of Labor Economics 2012 1:3.

Submit your manuscript to a SpringerOpen ${ }^{\circ}$ journal and benefit from:

- Convenient online submission

- Rigorous peer review

- Immediate publication on acceptance

- Open access: articles freely available online

- High visibility within the field

- Retaining the copyright to your article

Submit your next manuscript at $\gg$ springeropen.com 